Reprod. Nutr. Dévelop., 1985, 25 (2), 345-354.

\title{
Effects of dietary lipid level on ketonemia and other plasma parameters related to glucose and fatty acid metabolism in the rabbit during fasting
}

\author{
C. JEAN-BLAIN, Andrée DURIX
}

Laboratoire de Nutrition et d'Alimentation, Ecole Nationale vétérinaire de Lyon,

B.P. 31 ,

F-69752 Charbonnières Cedex, France.

Summary. The effects of a high-fat diet on ketonemia and other plasma parameters of gluconeogenesis and ketogenesis were studied in rabbits during feeding, during a 4-day fast, and again during refeeding. Arterial plasma glucose, lactate, total aminoacids, ketone bodies, insulin and glucagon were measured daily. In the fed state, the high-fat diet induced an increase in plasma NEFA and ketone bodies and a decrease in alaninemia. The most striking effect of the high-fat diet, compared with the normal low-fat diet, was the twofold increase of ketonemia during fasting, even though the difference in NEFA level after both diets was only $19 \%$. This effect was maintained throughout the fasting period. The high-fat diet also induced higher glycemia and lower alaninemia during further fasting. Insulinemia sharply decreased to a very low value from the beginning of fasting, but the high-fat diet did not have any particular effect. Glucagonemia was not different in the fed state than in fasting, whatever preceding diet was given. Therefore, the lipid content of the diet prior to fasting introduced important and persistent modifications in the triglycerides and glucose metabolism during fasting.

\section{Introduction.}

In all species, fasting induces a well-known shift in fuel metabolism which tends to facilitate the utilization of fats stored in adipose tissue and to preserve the nutritional status of glucose-dependent tissues. Thus, hepatic gluconeogenesis and ketogenesis are enhanced.

Major blood modifications observed shortly after the initiation of fasting are (1) an increase in the plasma concentrations of NEFA and ketone bodies, and (2) a decline in glycemia and insulinemia.

Numerous factors can modify the amplitude of these modifications in the metabolism and blood. For instance, the level of fasting ketonemia varies according to species (Bouchat, Doizé and Paquay, 1980 ; Brady et al., 1977 ; Schreiner, Lemons and Gresham, 1981; Williamson and Whitelaw, 1978; Zammit, 1983). 
The effectiveness of fasting gluconeogenesis and ketogenesis can be changed by the physiological or hormonal status (Hagenfeldt et al., 1981 ; Müller and Seitz, 1981 ; Pégorier et al., 1982 ; Varnam, Jeacock and Shepherd, 1978) ; fasting ketogenesis is suppressed during sepsis (Beisel and Wannemacher, 1980). The nutritional status preceding the fasting period can also modify the metabolic response of the entire organism or of liver gluconeogenesis or ketogenesis (Belo, Romsos and Leveille, 1976 ; Bouchat, Doizé and Paquay, 1980 ; Brady et al., 1977 ; Cowan, Vranic and Wrenshall, 1969 ; Mc Donald and Johnson, 1965; Pégorier et al., 1982 ; Peret et al., 1975).

Few data are available in rabbits on changes induced by starvation and the factors capable of modifying response to starvation. In this study, the effects of a diet enriched with $15 \%$ lard (considered as a high-fat diet for an herbivorous species like the rabbit) were evaluated according to changes in blood glucose and fatty acid metabolism over a 4-day fast and a following refeeding period of $96 \mathrm{~h}$. Marked changes in ketonemia, glycemia and plasma alanine concentration were induced by the high-fat diet over the entire fasting period. These modifications might be related to an increase in liver ketogenesis and impairment of peripheral tissue glucose tolerance.

\section{Material and methods.}

Animals, diets and protocol. - We used 16 rabbits of the New Zealand strain with an average weight of $1300-1500 \mathrm{~g}$ at the beginning of the study ; they were housed in individual cages and fed either a low-fat (LF) control diet or a high-fat (HF) experimental diet ad libitum for 20 days before fasting (table 1). Feed intake was measured during this period.

TABLE 1

Composition of diets

Components :

Low-fat (LF) diet

High-fat (HF) diet

\begin{tabular}{|c|c|c|}
\hline Cereals .. & 35 & 34,4 \\
\hline$\ldots \ldots \ldots \ldots \ldots \ldots$ & 22 & 24,6 \\
\hline Bran $\ldots \ldots \ldots \ldots \ldots \ldots \ldots$ & $\overline{25}$ & 8,2 \\
\hline Straw $\ldots \ldots \ldots \ldots \ldots \ldots \ldots$ & 13 & 4,1 \\
\hline Soya $\ldots \ldots \ldots \ldots \ldots \ldots \ldots$ & 1,7 & 10,4 \\
\hline Mineral Mix ................. & 3,3 & 3,3 \\
\hline 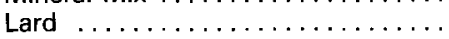 & 0 & 15,0 \\
\hline
\end{tabular}

Analysis :

Dry matter ................

Crude Proteins (Nx 6,25) . . . . . .

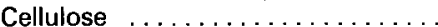

Ether Extract . . . . . . . . . . .

Minerals .................. 
The animals were then fasted for 4 days and refed for the same length of time with the LF diet.

Blood sampling. - Six days before the fast, permanent intravascular lines were established via the femoral artery. The catheters were not heparinized during the experiment. Blood samples were collected every day in the morning between 9 and $10 \mathrm{a} . \mathrm{m}$. on heparin $(2 \mathrm{ml})$ for substrate control or on EDTA + zymofren $(1000 \mathrm{~K} \mathrm{IU})$ for hormone control. All the samples were put into an ice-bath until the plasma could be separated by centrifugation and stored at $-30^{\circ} \mathrm{C}$.

Chemical analysis. - Glucose levels were determined using the glucose oxidase method of Trinder (1969) (glucibiotrol from Biotrol). Alanine (Williamson, 1974), lactate (Gutman and Wahlefeld, 1974), 3.0H butyrate (Williamson and Mellanby, 1974) and acetoacetate (Mellanby and Williamson, 1974) were determined according to standard enzymatic methods after deproteinization by TCA $0.7 \mathrm{M}$. Total aminoacids were determined by the method of Malangeau et al. (1963) and non-esterified fatty acids (NEFA) by the enzymatic method of Shimizu (1979) (NEFA C test Wako from Biolyon).

Insulin and glucagon were measured by radioimmunoassay ; a commercial kit (INSIK-3) (CEA-Sorin, France) was used for insulin determination ; crystalline rabbit insulin (Novo Research Institute, Denmark) was used as a standard. Glucagon was measured with the radioimmunoassay method of Faloona and Unger (1974) with Unger 30K antiserum.

Statistical analysis. - Results during fasting were compared with a twofactor (time and diets) analysis of variance. Student's t-test was used for the other comparisons.

\section{Results.}

Feed intake before fasting was depressed with the HF diet $(51.2 \mathrm{~g} / \mathrm{day} / \mathrm{kg}$ body weight) compared with the LF diet $(68.8 \mathrm{~g} /$ day $/ \mathrm{kg}$ body weight). This effect is common in rabbits eating a fat-rich diet. Despite the higher energy concentration in this diet, daily energy intake was lower $1720 \mathrm{Kj} / \mathrm{day} / \mathrm{kg}$ body weight) than with the LF diet $(790 \mathrm{Kj} /$ day/ $\mathrm{kg}$ body weight). Weight loss during fasting was similar in the two groups of rabbits, i.e. $9.55 \%$ of body weight. Results on plasma parameters are summarized in figures 1, 2 and 3 .

Fed state. - The HF diet led to modifications of certain plasma metabolites during the fed period. NEFA concentration increased from 0.07 to $0.31 \mathrm{mM}$ $(P<0.01)$; ketonemia increased slightly $(P<0.05)$. Glycemia and insulinemia increased but not significantly, and plasma alanine decreased $(P<0.01)$. On the other hand, there were no modifications in plasma lactate and total aminoacid concentrations.

Fasting. - The most striking effect of the HF diet was the twofold increase in fasting ketonemia. The hydroxybutyrate-acetoacetate ratio was not modified. In comparison, NEFA only increased by $19 \%$. These changes were maintained throughout the fasting period. 

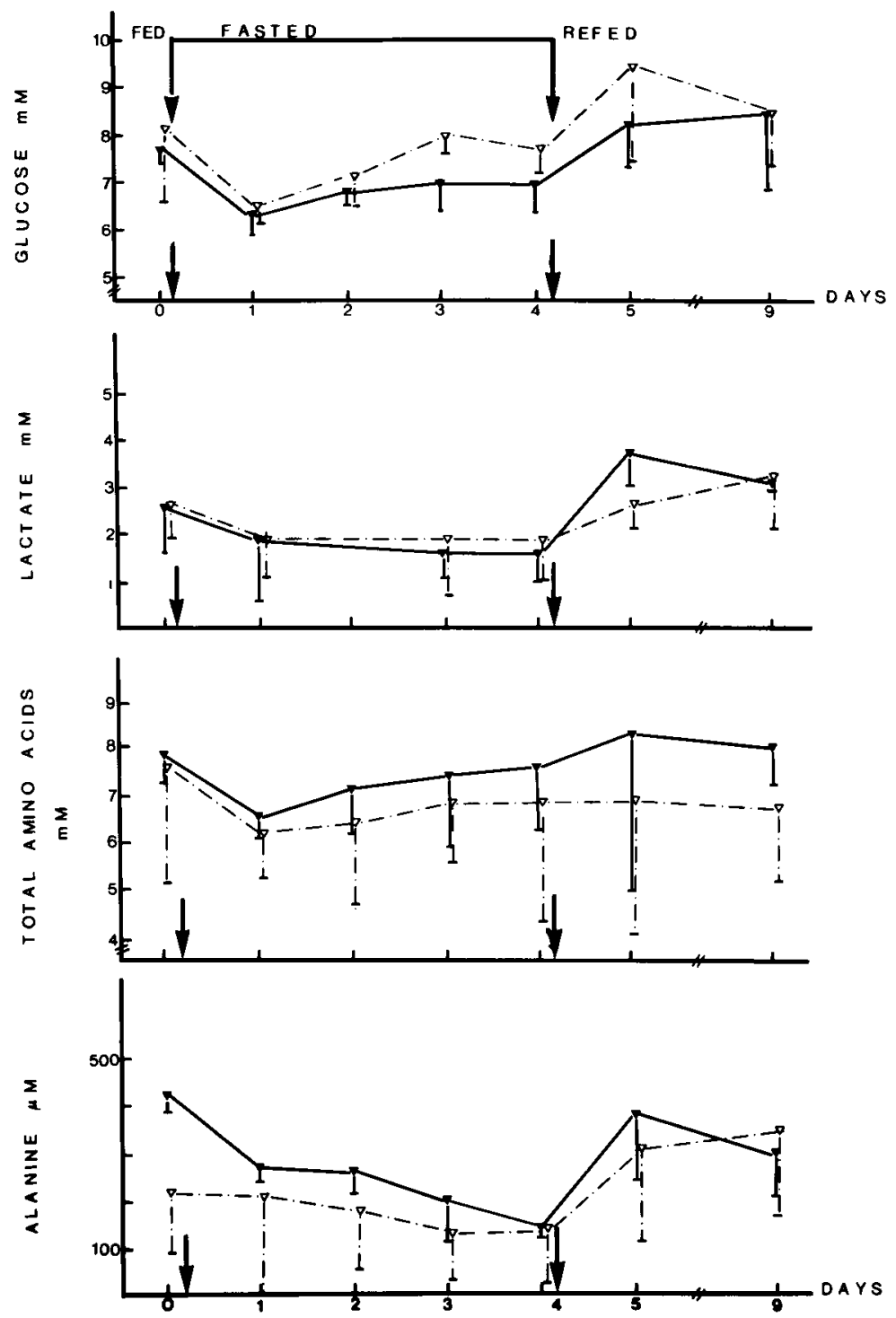

FIG. 1. - Effects of lipid percentage of the diet preceding fasting on plasma glucose, lactate, total aminoacids and alanine during the fed, fasted and refed periods (LF $\longrightarrow$; HF $\nabla-\cdot-\nabla)$. Statistical differences between diets: glucose: $\mathrm{P}<0,01$; lactate: NS; alanine: $P<0,01 ;$ total amino acids : NS.

FIG. 2. - Effects of lipid percentage of the diet preceding fasting on plasma $\beta$-hydroxybutyrate, total ketone bodies and non-esterified fatty acids during the fed, fasted and refed periods $(\mathrm{LF} \nabla$; HF $\nabla-\cdot-\nabla)$.

Statistical differences between diets: $\beta$-hydroxybutyrate: $\mathrm{P}<0,001$; total ketone bodies : $P<0,001$; non-esterified fatty acids : $P<0,01$. 

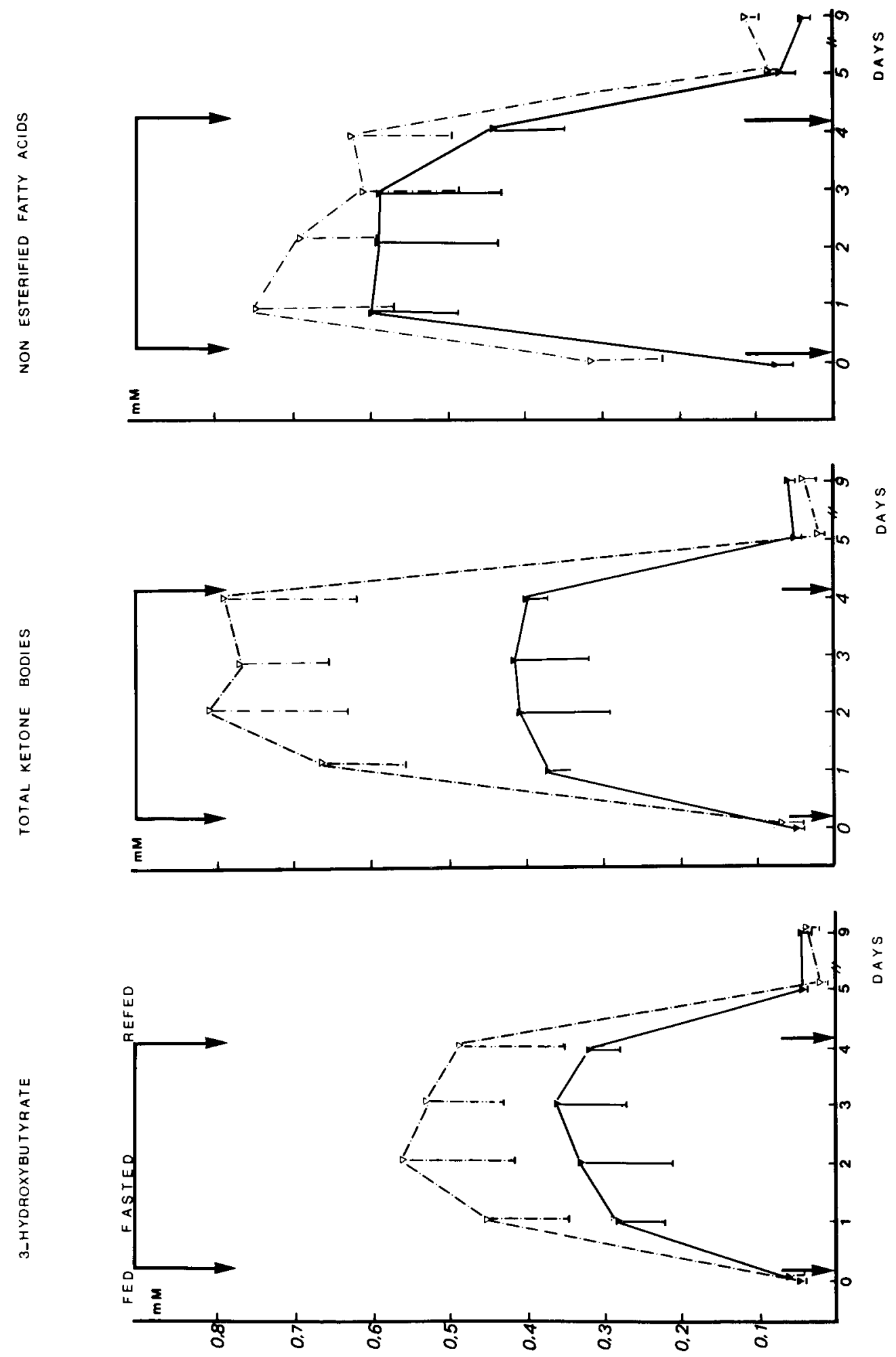
Fasting glycemia was lower after the $\mathrm{HL}$ diet than after the LF one $(P<0.01)$. In both cases, the lowest glycemia was reached after the first day of fasting. It increased when fasting was prolonged, particularly in the HF group so that fasting glycemia was equal to fed-state glycemia.

Fasting alaninemia was also lower in the HF group $(P<0.01)$ and no difference in alaninemia was observed between the fed and the fasted states. No significant modifications in lactate and total aminoacids were noted.

The hormonal status is interesting. Insulin decreased strongly after one day of fasting and then slightly over the following days. The HF diet led to a slight increase in insulinemia. Glucagonemia was not changed by either fasting or diet.

Refeeding. - On the first day of refeeding with the LF diet, rabbits previously fed with the HF diet showed a transient hyperglycemia ; this was not seen in those fed with the LF diet previously $(P<0.01)$. Lactate was also significantly higher $(P<0.05)$ at the beginning of refeeding.
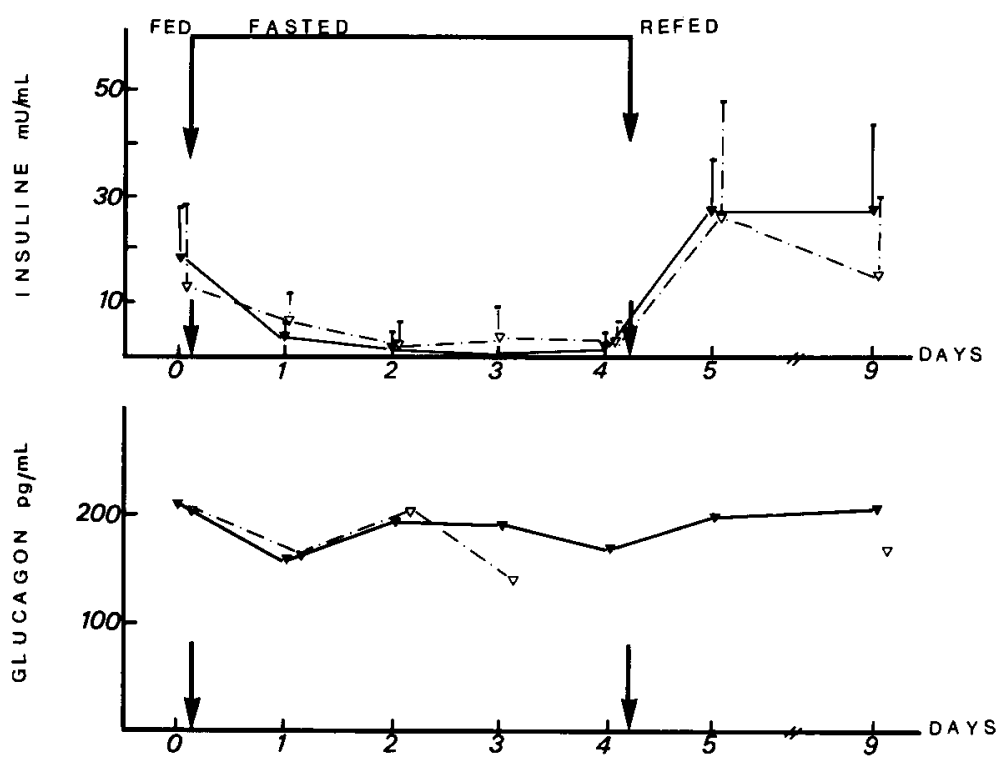

FIG. 3. - Effects of lipid percentage of the diet preceding fasting on plasma insulin and glucacon during the fed, fasted and refed periods (LF $\nabla ; \mathrm{HF} \nabla-\cdot-\nabla$ ).

\section{Discussion.}

Glycemia and insulinemia were shown to increase in the fed state in rats given a high-fat diet (Portha, Giroix and Picon, 1982). The same observation was made in rabbits in the fasted state (Lacombe and Nibbelink, 1983). In the latter experiment, the glucose tolerance test indicated that glucose tolerance had declined. Insulinemia also increased in dogs fed with a carbohydrate-free, high-fat 
diet, but glycemia was not modified and glucose tolerance decreased (Belo, Romsos and Leveille, 1976). High-fat, low-carbohydrate diets cause glucose tolerance to decrease in humans (Anderson and Herman, 1975).

Our observations in rabbits lead to analogous conclusions, i.e. the high level of non-esterified fatty acids and the slight increase in ketonemia indicate a shift towards lipid fuel in HF rabbits in the fed state. In other respects, in the fed state there was a discrepancy between the large decrease in alaninemia with the HF diet and the lack of total aminoacid variations. Rabbits fed with the HF diet had a lower protein intake; but the decrease in alaninemia could not be imputed to this since the total aminoacid level did not vary. Therefore, this decrease might be related to augmented gluconeogenesis due to alanine, correlated with a decline in dietary glucose intake.

Plasma aminoacid concentration usually decreased markedly at the onset of fasting and then more slowly if fasting was prolonged. In humans, this further decrease is correlated with lower extraction of aminoacids from muscle tissue (Aoki, 1981 ; Felig et al., 1969), as well as with a sparing effect on body protein and the preferential utilization of ketone bodies as fuel. In rabbits, this pattern was found for alanine which is considered as the principal gluconeogenic aminoacid, at least at the beginning of fasting.

Paradoxically, plasma total aminoacid levels were stable at the same time after the HF diet, or increased slightly after the LF diet. Consequently, it is probable that other aminoacids, such as alanine, form the major gluconeogenic substrate in rabbits when fasting is prolonged.

Fasting ketonemia was lower in our rabbits than it is in rats, and was considerably enhanced by the HF diet. On the other hand, NEFA increase due to this diet was slight and could account for the enhanced formation of ketone bodies. Data on various species (Bouchat, Doizé and Paquay, 1980 ; Brady et al., 1977; Zammit, 1983) show no direct correlation between plasma NEFA concentration and ketonemia.

Most of the increase in ketonemia must have been a result of augmented liver ketogenesis ; high-fat diets are known to enhance ketogenesis in isolated rat liver cells (Malewiak et al., 1983 ; Williamson and Whitelaw, 1978). The main reason for this could be a lower level of malonyl-CoA in the hepatocytes, followed by a moke unrestrained carnitine-acyltransferase activity in mitochondrial membranes; ketogenesis would thus be increased for the same uptake of fatty acid by the liver. Glucagon probably plays no part in the decrease of malonyl-CoA synthesis in rabbits; glucagonemia was not modified by either fasting or diet. It may have a minor role in the genesis of fasting hyperketonemia in this species. A comparison can be made with ruminants in which glucagonemia increases only after prolonged fasting (Schreiner, Lemons and Gresham, 1981) and glucagon has a poor effect on ketogenesis from oleate in isolated liver cells (Donaldson and Pogson, 1983). The higher ketonemia in starved rabbits (fed the HF diet) could also have resulted from initially lower insulin levels, despite the fact that the difference was not significant (fig. 3). The augmentation in ketonemia could also be related to a mechanism which does not involve the regulation of carnitineacyltransferase activity. In rabbits we found that high-fat diets increase 
ketogenesis from butyrate in isolated liver cells (Jean-Blain, 1982), even though the transport of this short-chain fatty acid through the mitochondrial membrane does not depend on the carnitine acyltransferase system and thus is not regulated by the intracellular level of malonyl-CoA.

Reçu en juin 1984.

Accepté en octobre 1984.

Acknowledgements. - We wish to thank C. Huc and M. Carcelen for expert technical assistance and R. Cohen (Unité INSERM 97, Lyon) who carried out the glucagon radioimmunoassays.

Résumé. Influence de la teneur en lipides de la ration sur la cétonémie et les autres paramètres sanguins du métabolisme des acides gras et du glucose chez le lapin au cours du jeâne.

Les effets d'un régime hyperlipidique sur la cétonémie et sur les autres paramètres plasmatiques de la gluconéogenèse et de la cétogenèse ont été étudiés chez le lapin à l'état alimenté, au cours d'un jeûne de quatre jours, et pendant la période de réalimentation consécutive.

Le glucose, les acides aminés totaux, l'alanine, les acides gras non estérifiés (NEFA), les corps cétoniques, l'insuline et le glucagon ont été déterminés quotidiennement sur des animaux soumis préalablement à un régime renfermant $15 \%$ de suif et sur des animaux témoins ayant reçu un régime pauvre en lipides.

A l'état alimenté, le régime hyperlipidique provoque une élévation des taux plasmatiques de NEFA et de corps cétoniques et une diminution de l'alaninémie. L'effet le plus marquant du régime hyperlipidique est la multiplication par deux de la cétonémie de jeûne par rapport au régime normal pauvre en lipides alors que la différence du taux de NEFA après les deux régimes n'est que de $19 \%$. Cet effet est maintenu pendant toute la période de jeûne. Le régime hyperlipidique induit une glycémie plus haute et une alaninémie plus basse au cours du jeûne ultérieur. L'insulinémie décroît rapidement vers une valeur très basse dès le début du jeûne sans que l'on puisse mettre en évidence un effet particulier du régime hyperlipidique. Le glucagon ne varie pas au cours du passage entre l'état nourri et le jeûne chez le lapin, quelle que soit la nature de la ration précédente.

Le taux de lipides de la ration précédant le jeûne introduit donc des modifications importantes et persistantes du métabolisme des triglycérides et du glucose pendant le jeûne.

\section{References}

ANDERSON J. W., HERMAN R. H., 1975. Effects of carbohydrate restriction on glucose tolerance of man and reactive hypoglycemic patients. Am. J. clin. Nutr., 28, 748-755.

AOKI T. T., 1981. Metabolic adaptations to starvation, semistarvation, and carbohydrate restriction, 161-177. In Nutrition in the 1980s: Constraints on our knowledge. Alan R. Liss, Inc, 150 Fifth Avenue, New York, NY 10011.

BELO P. S., ROMSOS D. R., LEVEILLE G. A., 1976. Influence of diet on glucose tolerance, on the rate of glucose utilization and on gluconeogenic enzyme activities in the dog. J. Nutr., 106, 1465-1474.

BEISEL W. R., WANNEMACHER R. W., 1980. Gluconeogenesis, ureagenesis and ketogenesis during sepsis. J. Parent. Ent. Nutr., 4, 277-285.

BOUCHAT J. Cl., DOIZÉ F., PAQUAY R., 1980. Effects of fasting on blood composition and 
nitrogen losses in the adult sheep depending on previous diet and body weight. Reprod. Nutr. Dévelop., 20, 77-92.

BRADY L. J., ARMSTRONG M. K., MUIRURI K. L., ROMSOS D. R., BERGEN W. G., LEVEILLE G. A., 1977. Influence of prolonged fasting in the dog on glucose turnover and blood metabolites. J. Nutr., 107, 1053-1061.

COWAN J. S., VRANIC M., WRENSHALL G. A., 1969. Effects of preceding diet and fasting on glucose turnover in normal dogs. Metabolism, 18, 319-330.

DONALDSON I. A., POGSON C. I., 1983. The effects of glucagon and $3^{\prime}-5^{\prime}$ cyclic AMP on the metabolism of palmitate by isolated hepatocytes from adult sheep. Proc. Nutr. Soc., $42 \mathrm{~A}$.

FALOONA G. R., UNGER R. H., 1974. In JAFFÉ B. M., BEHRMAN M. R. Methods of hormona radioimmunoassay. Acad. Press, New York 317-320.

FELIG P., OWEN O. E., WAHREN J., CAHILL G. F., 1969. Amino acid metabolism during prolonged starvation. $J$. clin. Invest., 48, 584-594.

GUTMAN I., WAHLEFELD A. W., 1974. In BERGMEYER H. U., Methods of enzymatic analysis, vol. 3, 1464-1468. Acad. Press, New York.

HAGENFELDT L., WENNELUND A., FELIG P., WAHREN J., 1981. Hepatic gluconeogenesis and ketogenesis in hyperthyroidism. Life Sci., 28, 1851-1856.

JEAN-BLAIN C., 1982. Effect of length of fasting and diet preceding fasting on ketogenesis in rabbit isolated liver cells. 6th Conf. G.E.R. C.H.I.C., Société de Chimie biologique France. Tours May 1982.

LACOMBE C., NIBBELINK M., 1983. Insulin effects on the lipoprotein increase induced by a semisynthetic saturated-fat diet. Diab. Metab., 9, 35-41.

MALANGEAU P., BOUDON R., MICAISE A. M., MASSON B., 1963. Dosage des acides aminés dans les liquides de l'organisme (Amino acids determination in body fluids). Ann. Biol. clin., 21, 1-13.

MALEWIAK M. I., GRIGLIO S., KALOPISSIS A. D., LE LIËPVRE X., 1983. Oleate metabolism in isolated hepatocytes from lean and obese Zucker rats. Influence of a high fat diet and in vitro response to glucagon. Metabolism, 32, 661-668.

MC DONALD B. E., JOHNSON B. C., 1965. Metabolic response to realimentation following chronic starvation in the adult male rat. J. Nutr., 87, 161-167.

MELLANBY J., WILLIAMSON D. H., 1974. In BERGMEYER H. U., Methods of enzymatic analysis, vol. 4, 1840-1843. Acad. Press, New York.

MÜLLER M. J., SEITZ H. J., 1981. Starvation-induced changes of hepatic glucose metabolism in hypo- and hyperthyroid rats in vivo. J. Nutr., 111, 1370-1379.

PÉGORIER J. P., DUEEE P. H., GIRARD J., PERET J., 1982. Development of gluconeogenesis in isolated hepatocytes from fasting or suckling newborn pigs. J. Nutr., 112, 1038-1046.

PERET J., CHANEZ M., COTA J., MACAIRE 1., 1975. Effects of quantity and quality of dietary protein and variation in certain enzyme activities on glucose metabolism in the rat. J. Nutr., 105, 1525-1534.

PORTHA B., GIROIX M. H., PICON L., 1982. Effects of diet on glucose tolerance and insulin response in chemically diabetic rats. Metabolism, 31, 1194-1199.

SCHREINER R. L., LEMONS J. A., GRESHAM E. L., 1981. Metabolic and hormonal response to chronic maternal fasting in the ewe. Ann. Nutr. Metab., 25, 38-47.

SHIMIZU S., INOUE K., TANI Y., YAMADA H., 1979. Enzymatic microdetermination of serum free fatty acids. Anal. Biochem., 98, 341-435.

TRINDER P., 1969. Determination of blood glucose. Ann. clin. Biochem., 6, 24.

VARNAM G. C., JEACOCK M. K., SHEPHERD D. A. L., 1978. Hepatic ketone body metabolism in developing sheep and pregnant ewes. Br. J. Nutr., 40, 359-367.

WILLIAMSON D. H., 1974. In BERGMEYER H. U., Methods of enzymatic analysis, vol. 4, 1679-1682. Acad. Press, New York.

WILLIAMSON D. H., MELLANBY J., 1974. In BERGMEYER H. U., Methods of enzymatic analysis, vol. 4, 1836-1839. Acad. Press, New York.

WILLIAMSON D. H., WHITELAW E., 1978. Physiological aspects of the regulation of ketogenesis. Biochem. Soc. Symp., 43, 137-161.

ZAMMIT V. A., 1983. Regulation of hepatic fatty acids oxidation and ketogenesis. Proc. Nutr. Soc., 42, 289-302. 